\title{
Monitoring Bacteroides spp. markers, nutrients, metals and Escherichia coli in soil and leachate after land application of three types of municipal biosolids
}

Crystal A. McCall, Katerina S. Jordan, Marc B. Habash, and Kari E. Dunfield

This is the peer reviewed version of the article, which has been published in final form at https://doi.org/10.1016/j.watres.2014.12.004 (C) 2015. This manuscript version is made available under the CC-BY-NC-ND 4.0 license http://creativecommons.org/licenses/bync-nd/4.0/.

Suggested Citation: McCall, Crystal A., Jordan, Katerina S., Habash, Marc B., and Dunfield, Kari E. (2015), Monitoring Bacteroides spp. markers, nutrients, metals and Escherichia coli in soil and leachate after land application of three types of municipal biosolids, Water Research, 70: 255-265. https://doi.org/10.1016/j.watres.2014.12.004. 


\title{
Monitoring Bacteroides spp. markers,
} nutrients, metals and Escherichia coli in soil and leachate after land application of three types of municipal

\author{
Crystal A. McCall, Katerina S. Jordan, Marc B. Habash, and Kari E. Dunfield
}

Affiliation: School of Environmental Sciences, University of Guelph, Guelph, Ontario N1G 2W1, Canada

Abstract: A lysimeter-based field study was done to monitor the transfer of culturable Escherichia coli, general (ALLBAC), human (Hf183) and swine (PIG-BAC-1) specific $16 S$ rRNA Bacteroides spp. markers, nutrients and metals through soils and leachate over time following land application of a CP1/Class A as well as two CP2/Class B municipal biosolids (MBs). Hf183 markers were detected up to six days following application in soils receiving dewatered and liquid MBs, but not in leachate, suggesting their use in source tracking is better suited for recent pollution events. The CP2/Class B biosolids and swine manure contributed the highest microbial load with E. coli loads (between 2.5 and $3.7 \log$ CFU $(100 \mathrm{~mL})^{-1}$ ) being greater than North American concentration recommendations for safe recreational water. ALLBAC persisted in soils and leachate receiving all treatments and was detected prior to amendment application demonstrating its unsuitability for identifying the presence of fecal pollution. A significant increase in $\mathrm{NO}_{3}-\mathrm{N}$ (for Lystek and dewatered MBs) and total-P (for dewatered and liquid $M B s$ ) in leachate was observed in plots receiving the CP1/Class $A$ and CP2/Class $B$ type MBs which exceeded North American guidelines, suggesting impact to surface water. Metal (As, $\mathrm{Cd}, \mathrm{Cr}, \mathrm{Co}, \mathrm{Cu}, \mathrm{Pb}, \mathrm{Mo}, \mathrm{Ni}, \mathrm{Se}, \mathrm{Zn}$ and $\mathrm{Hg}$ ) transfer was negligible in soil and leachate samples receiving all treatments. This study is one of the first to examine the fate of $E$. coli and Bacteroides spp. markers in situ following the land application of MBs where surface runoff does not apply.

Keywords: qPCR, Bacteroides spp., fecal indicator organisms, fecal contaminants, fecal source tracking 
Abbreviations: MBs, Municipal biosolids; DAA, Days after amendment; CFU, Colony forming unit; NO3eN, Nitrateenitrogen; NH4eN, Ammonium-nitrogen; Total-P, Total phosphorus; MAP, Monoammonium phosphate; CP1, Criteria for pathogens category 1; CP2, Criteria for pathogens category 2; PCR, Polymerase chain reaction; qPCR, Quantitative polymerase chain reaction; dw, Dry weight; GTI, Guelph Turfgrass Institute; FST, Fecal source tracking; FAM, Fecal associated marker.

\section{Introduction}

Municipal biosolids (MBs) are a solid by-product of wastewater treatment, and are valuable soil amendments due to their high nutrient and organic matter contents. Biosolids are rich in macro-nutrients including nitrogen and phosphorus, and contain micro-nutrients including zinc, copper, iron, and molybdenum which contribute to optimum plant growth and soil health (Lu et al., 2012). However, MBs can also be nonpoint source contributors of metals, human-pathogens and xenobiotics (Singh et al., 2006). The excessive nutrient and metal loads either from improper application rates or unexpected bioconversion is a concern. Increasing use of these land amendments has led governing agencies to define and regulate maximum nutrient and metal content as well as their land application rates in an effort to minimize these impacts (CCME, 2010; Standards for the Use or Disposal of Sewage Sludge, 1999). However, there is always potential for leaching and run-off of microbial contaminants from land-applied biosolids into surface water and groundwater after extreme weather events including heavy rainfall or flooding (Jamieson et al., 2002; Samarajeewa et al., 2012).

In Canada and the US, MBs are regulated based on their biological content, and classified as CP1 or Class A, if they meet minimum standards for Escherichia coli, Salmonella, Helminth ova and enteric virus or CP2 or Class B, if the human pathogen levels are unknown, and the E. coli levels are $\leq 2 \times 10^{6} \mathrm{CFU}(100 \mathrm{~mL})^{-1}$ (Ontario, 2002; Standards for the Use or Disposal of Sewage Sludge, 1999). MBs can contain other human pathogens that are not reported or enumerated under the current regulations, including Legionella pneumophila, Staphylococcus aureus, Clostridium difficile and Mycobacterium spp. (Bibby et al., 2010; Viau and Peccia, 2009). 
Treatment processes for MBs can be designed to eliminate many pathogens (Singh et al., 2006); however, unregulated category (CP2, or Class B) products are frequently used as a soil amendment on agriculture lands, in part because wastewater treatment plants often lack the capability to test for the presence of viruses and helminth ova and therefore cannot guarantee their absence. E. coli culture methods are inexpensive and straight-forward; however, their use as a proxy for the presence of enteric humanpathogens has been questioned based on the ubiquity of $E$. coli in mammals as well as long term survival in environmental matrices (Byappanahalli et al., 2006; Ishii et al., 2006). Molecular methods that use host-specific fecal associated markers (FAMs) found in Bacteroides spp. can determine both presence and source of fecal contamination (Mieszkin et al., 2009; Shanks et al., 2008). Determining sources of pollution allows for best management practices and mitigation strategies to attenuate or prevent future contamination events. The ability to use host-specific Bacteroides spp. markers for fecal source tracking (FST) is dependent on their survivability under environmental conditions. The persistence of FAMs in the environment has been assessed in water samples. These studies have shown FAM persistence to be highly variable depending upon the water type, environmental conditions, and the particular FAM being evaluated (Bae and Wuertz, 2009; Seurinck et al., 2005; Tambalo et al., 2012). Therefore, in order to understand the ability to use FAMs to track fecal pollution resulting from the application of a biosolid to soil, it is necessary to understand their persistence and transport through a soil profile. The soil matrix can be dynamic; therefore, the transfer, movement and persistence of fecal contaminants in soil and surface water can vary greatly with edaphic conditions. In the current study we used hydrologically isolated $118 \mathrm{~L}$ lysimeters in a field-based study to quantify the survival of FAMs in the soil and their potential to be transported in leachate. This study is the first to examine the fate of human and swine-specific Bacteroides spp. markers in situ following the land application of MBs; it is an important step in assessing the suitability of using Bacteroides markers in tracking movement of fecal contaminants from MBs through soil into water. In addition, by quantifying nitrogen, phosphorus, metal and E. coli concentrations in soil and leachate over a field season we have been able to assess 
potential for land application of two classes of MBs to impact water quality of tile or shallow ground water.

\section{Methods}

\subsection{Sample site description and experimental set-up}

Precipitation amounts, air temperatures, and average soil temperatures during the 2011 (July to November) and 2012 (July to September) sampling seasons were retrieved from the Guelph Turfgrass Institute (GTI) in Guelph, Ontario, Canada (43 deg 33' N 80 deg 13' W, elevation $325 \mathrm{~m}$ ) climate and soil conditions records. Hydrologically isolated highdensity polyethylene lysimeters $(118 \mathrm{~L}$ ) were previously constructed and described (Roy et al., 2001). Each lysimeter was buried and filled with a soil profile consisting of a $35 \mathrm{~cm}$ A horizon (sandy loam), a $25 \mathrm{~cm} \mathrm{~B} \mathrm{horizon} \mathrm{(loamy} \mathrm{sand)} \mathrm{and} \mathrm{a} 25 \mathrm{~cm} C$ horizon (sand) at the GTI in 1998. A $1 / 4$ inch pea gravel layer was below the $C$ horizon to allow for leachate filtration to be vacuum pumped through a fitted $1.27 \mathrm{~cm}$ o.d. nylon collection tube. Forty-two lysimeters were arranged in two parallel lines, spaced $1 \mathrm{~m}$ apart and surrounded by previously established Kentucky bluegrass sod. Prior to use in the current experiment, the area surrounding the lysimeters was leveled to prevent unnatural ponding or runoff.

\subsection{Description of amendments}

Liquid, dewatered, and Lystek MBs were obtained from the Guelph Wastewater Treatment Plant (Guelph, ON). Liquid biosolids refers to the fluids remaining after raw sludge solids undergo a mesophilic anaerobic digestion for 2 weeks at $36^{\circ} \mathrm{C}(0.4 \%$ dry matter), and are classed as CP2. The dewatered MBs are the sludge portion from the digester that are mixed with a polymer and passed over a belt filter press $(13.1 \%$ dry matter), and are classed as CP2. For the Lystek product, the dewatered solids are further treated with $\mathrm{KOH}, 70^{\circ} \mathrm{C}$ temperatures and mixing (22.8\% dry matter). The Lystek treatment aims to provide an end product classified as CP1 biosolids under the Nutrient Management Act (Ontario, 2002). Liquid swine manure treatment was included and provided an organic amendment comparison that was E. coli positive, but $\mathrm{Hf} 183$ negative. The source was untreated piglet manure obtained from reservoirs at the University of Guelph's Arkell Research Station (Guelph, ON) (5.27\% dry matter). 
Manure and MBs were stored in $20 \mathrm{~L}$ plastic buckets and transported at ambient temperatures up to $6 \mathrm{~km}$ to the field site, where they were applied the same day they were delivered. Monoammonium phosphate (MAP) (11-52-0) fertilizer used as a negative microbial control.

\subsection{Experimental design and field operations}

For the 2011 field season, lysimeters were randomly assigned to receive one of five amendments in quadruplet (Total $n=20$ ). In 2012, lysimeters that had not had any prior amendments were used, and were randomly assigned to receive one of the five amendments in triplicate (Total $n=15$ ).

The five amendments - $3 \mathrm{MBs}$, liquid swine manure and MAP fertilizer, were applied on July 7th 2011 and July 5th 2012, for the 2011 and 2012 field seasons, respectively. The MBs were applied according to Ontario target rates (Ontario, 2002) with an application rate of $7.1 \mathrm{t}$ (ha) $)^{-1}$ for dewatered; $2.1 \mathrm{t}(\mathrm{ha})^{-1}$ for liquid and $7.8 \mathrm{t}(\mathrm{ha})^{-1}$ for Lystek all on a dry weight basis. The rate for swine manure was based on the standard practice of 60 $000 \mathrm{~L}$ (ha)-1 wet weight. The rate for the MAP fertilizer control was based on $90 \mathrm{~kg} \mathrm{~N}$ (ha) $)^{-1}$ requirements for turfgrass sod as published by the Ontario Ministry of Food, Agriculture and Rural Affairs (OMAFRA, 2009). Amendments were incorporated to a depth of $15 \mathrm{~cm}$ by hand mixing with sterile instruments to ensure uniformity and to prepare the seedbed. In 2012, lysimeter soil was pre-tilled prior to adding amendments according to suggested best management practices for application of liquid manure (Samarajeewa et al., 2012).

Turfgrass was selected as the candidate crop, as it is a crop grown in Ontario that has a high nitrogen requirement particularly during establishment and is not used for human or animal consumption (Tesfamariam et al., 2009). Perennial ryegrass (Lolium perenne L.) was seeded one day after amendment at a seeding rate of $20 \mathrm{~kg}(\mathrm{ha})^{-1}$. Following seeding, no additional amendments were added. An irrigation and mowing schedule typical for successful sod establishment was followed (OMAFRA, 2009). Since under Ontario climactic conditions sod has a 18-24-month maturity period, the crop was not harvested during this field experiment. 


\subsection{Soil and leachate collection and storage}

During the 2011 sampling period, soil samples were taken one day prior to amendment as well as 6, 29 and 141 days after amendment (DAA); in 2012 soil samples were taken one day prior to amendment, and 8 and 119 DAA. The cores were removed prior to significant root growth and at the end of the field experiment so gaps in the soil profile did not influence natural leaching processes. For each lysimeter, soil was sampled along a transect using a $2 \times 25 \mathrm{~cm}$ core with 5 cores being removed each time and composited prior to further analysis. For the quantification of microbial fecal indicators, soil was stored at $4^{\circ} \mathrm{C}$ and used within $24 \mathrm{~h}$; for all other analysis, soil was stored at $20^{\circ} \mathrm{C}$ prior to use.

Leachate was collected from each hydrologically-isolated lysimeter using a vacuum pump system installed on the soil surface that was attached to a sterile collection tube and Nalgene bottle. At each sample time, $1 \mathrm{~L}$ of leachate was removed for analysis. All leachate remaining in the lysimeters was then removed and the total volume recorded in order to determine the total load of contaminants. In 2011 sampling leachate was collected prior to amendment and 3, 8, 15, 22, 30, 57, 75, 105 and 133 DAA. In 2012 leachate was collected prior to amendment and 1, 5, 12, 20, 33 and 71 DAA. Subsamples $(15 \mathrm{~mL})$ from all leachate samples were collected, immediately treated with a $2 \% \mathrm{HNO}_{3}$ solution and stored at $4{ }^{\circ} \mathrm{C}$ until total-P and metal analyses were performed.

\subsection{Quantification of microbial fecal indicators}

\subsubsection{Enumeration of Escherichia coli}

Serial dilutions of soil or MBs were prepared in a phosphate buffer saline solution (PBS) and plated onto differential coliform agar (DCA) (Oxoid Limited Nepean, ON, Canada). Culturable $E$. coli in leachate samples were enumerated by membrane filtration - direct count as described in Standard Method 9222B (APHA 1999), the only modification was the use of $0.2 \mu \mathrm{m}$ pore size filters with $25 \mathrm{~mm}$ diameters. Filters were placed atop DCA and incubated for $48 \mathrm{~h}$ at $35^{\circ} \mathrm{C}$.

\subsection{2. $16 \mathrm{~S}$ rRNA Bacteroides spp. Marker analysis}

Genomic DNA was extracted from $0.25 \mathrm{~g}$ of soil, manure and MBs using a MO BIO Power Soil kit. DNA was extracted from filtered leachate samples $(250 \mathrm{~mL})$ using an 
MO BIO Power Water kit (MoBio Laboratories, Inc. Carlsbad, CA, USA). DNA was eluted in PBS buffer to a final volume of $100 \mu \mathrm{L}$, and stored at $-80^{\circ} \mathrm{C}$. The quality and purity of DNA was checked by $1 \%$ agarose gel electrophoresis and NanoDrop 8000 spectrophotometry (NanoDrop Technologies, Wilmington, DE).

Bacteroides spp. markers were quantified by real-time quantitative PCR (qPCR) in an iQ5 thermal cycler (Bio-Rad Laboratories, Mississauga, ON, Canada). Primer pairs included: the general Bacteroides-Prevotella group (ALLBAC: qBAC560f and Bac708R) (Bernhard and Field, 2000; Okabe et al., 2007), human-specific (Hf183: Hf183F and Hf183R) (Seurinck et al., 2005) and swine specific (PIG-BAC-1: qPS422F and qBac581R) (Okabe et al., 2007) Bacteroides. For Hf183 and PIGBAC-1 markers, a 25 $\mu \mathrm{L}$ volume assay was used with BioRad $\mathrm{iQ}^{\mathrm{TM}}$ SYBR®Green supermix, $1 \mu \mathrm{L}$ template DNA (average of $62 \mathrm{ng}$ DNA), $400 \mathrm{nM}$ of each primer and RNase/DNase-free water with an initial denaturation step of $5 \mathrm{~min}$ at $95^{\circ} \mathrm{C}$ followed by 40 cycles of $95^{\circ} \mathrm{C}$ for $15 \mathrm{~s}$ and a $30 \mathrm{~s}$ annealing at $59^{\circ} \mathrm{C}$ for $\mathrm{Hf} 183$ and $62^{\circ} \mathrm{C}$ for PIG-BAC-1. ALLBAC markers were amplified with SsoFast EvaGreen ${ }^{\circledR}$ Supermix, $1 \mu \mathrm{L}$ template DNA (average of $62 \mathrm{ng}$ DNA), $400 \mathrm{nM}$ primers and RNase/ DNase free water in $20 \mu \mathrm{L}$ volume assays. qPCR assays using SsoFast EvaGreen ${ }^{\circledR}$ Supermix were conducted with an initial denaturation step of 2 min at $98^{\circ} \mathrm{C}$ followed by 40 cycles of $98^{\circ} \mathrm{C}$ for $5 \mathrm{~s}$ and a $10 \mathrm{~s}$ annealing at $62^{\circ} \mathrm{C}$. Random qPCR products containing each of the primers (ca. $20 \%$ of samples) were run out on a $1 \%$ agarose gel to verify proper sequence size. A melt curve analysis was done to verify specific target amplification with 36 cycles of $30 \mathrm{~s}$ at $75^{\circ} \mathrm{C}-95^{\circ} \mathrm{C}$; and for ALLBAC: $41 \mathrm{cycles}$ of $10 \mathrm{~s}$ at $65^{\circ} \mathrm{C}-95^{\circ} \mathrm{C}$. Triplicate no template controls were run with every assay.

Serial dilutions of linearized plasmid DNA $\left(10^{8}\right.$ to $\left.10^{1}\right)$ containing the target genes were used to construct the standard curves. The standards were produced by ligating the desirable marker sequences into $\mathrm{PCR}^{\text {TM }}{ }^{2}$.1-TOPO ${ }^{\circledR}$ vectors, as per manufacturer's instructions (Life Technologies). The marker sequences were amplified using PCR with ALLBAC markers being isolated from Bacteroides fragilis pure culture, PIG-BAC-1 from swine feces and HF183 from DNA that had been previously extracted from dewatered biosolids. The PCR efficiency limits were between 95 and 110\%, slopes between -3.1 
and -3.3 and a $R^{2}$ value of 0.99 or higher. The limit of detection for all $\mathrm{QPCR}$ analyses was greater than 10 gene copies.

\subsection{Quantification of nutrients and metals (2012 field season only)}

\subsection{1. $\mathrm{MB}$ and manure analysis}

MBs and manure samples were analysed by University of Guelph Laboratory Services (Guelph, ON). In brief, a partial extraction was done on dried, ground municipal biosolids and swine manure with a mixture of hot acid and brought to volume with Nanopure water. The extract was measured by Vista-Pro inductively coupled plasmid optical emission spectrometry (ICP-OES) (Varian Inc., CA, U.S.A.) for $\mathrm{Cd}, \mathrm{Cr}, \mathrm{Co}, \mathrm{Cu}$, $\mathrm{Mo}, \mathrm{Ni}, \mathrm{Pb}, \mathrm{Zn}$ (MOE, 2002). Additional extract was further processed and measured by cold vapour atomic absorption spectroscopy (AAS) for mercury (MOE, 1997) and hydride generation AAS (MOE, 1999) for selenium and arsenic. Air dried, sieved manure and $\mathrm{MB}$ samples were mixed with $0.5 \mathrm{M} \mathrm{NaHCO}_{3}$ and extracts were analyzed with segmented flow analysis on the Seal AA3 (SEAL Analytical, Wisconsin, USA) for Olsen-P (Reid, 1998). Manure and MBs were extracted with $2 \mathrm{M} \mathrm{KCl}$ and analyzed using the Seal $A Q 2$ for $\mathrm{NO}_{3}$ (USEPA, 1993) for $\mathrm{NH}_{4}$ (USEPA, 1983).

\subsubsection{Total-phosphorus and metals analysis in soil and leachate}

Soil was defrosted, dried, ground and sieved twice $(2.5 \mathrm{~mm}$ followed by $0.25 \mathrm{~mm}$ plastic mesh). Soil samples $(5 \mathrm{~g})$ were digested and filtered using US EPA Method 3051A (USEPA, 2007). Leachate previously treated with $\mathrm{HNO}_{3}$ was analysed using Vista-Pro ICP-OES by the Environmental Science Analytical Lab (University of Guelph, ON, CA).

\subsubsection{Inorganic nitrogen in soil and leachate}

Inorganic nitrogen was extracted from $5 \mathrm{~g}$ of moist soil using standard $\mathrm{KCl}$ extraction methods (Maynard et al., 2008). Leachate samples $(250 \mathrm{~mL}$ ) were filtered through Whatman No. 42 filters (Whatman plc, ME, USA) prior to analysis. $\mathrm{NO}_{3}-\mathrm{N}$ was analyzed in $15 \mathrm{~mL}$ of filtered leachate using a cadmium reduction (Technicon Intrument Corporation, 1971), and $\mathrm{NH}_{4}-\mathrm{N}$ using the Berthelot reaction (Searle, 1984), with segmented flow analyses with the SEAL AA3. 


\subsection{Statistical analysis}

All data were normalized to mean abundance per gram dry matter for soils, biosolids and manure. The leachate data were normalized to mean abundance per $100 \mathrm{~mL}$. Data analysis was completed using Statistical Analysis Software for Windows version 9.3 (SAS Institute, Cary, NC, USA). A multiple means comparison was done using a Tukey adjustment. Statistical significance was accepted at $P<0.05$, unless otherwise noted, in cases where it is important to see biological trends that may be marginally significant. The least square mean estimates for the concentration, using a mixed model, and count data, using a Poisson distribution, was used for plotting the mean concentration data in scatter and box-plots. Background mean concentration results for the Bacteroides spp. markers, culturable E. coli, nutrients and metals were used as covariates for analysis of the corresponding mean abundance and persistence following amendment application. A Kendall Taub correlation coefficient for non-parametric data was used to determine any relationships between nutrient and microbial concentrations.

\section{Results and discussion}

\subsection{Culturable E. coli and Bacteroides spp. marker loads contained in MBs and swine manure}

In each year, the CP2/Class B MBs (dewatered and liquid) both contained levels of $E$. coli and ALLBAC markers exceeding 5 log CFU or copies (g) ${ }^{-1} \mathrm{dw}$ (Table 1). In 2012, the abundance of culturable $E$. coli in dewatered MBs surpassed the $2 \times 10^{6} \mathrm{CFU}$ or MPN (g) ${ }^{-1}$ guidelines outlined in Ontario's Nutrient Management Act and US EPA's Part 503 Biosolids Rule (Ontario, 2002; Standards for the Use or Disposal of Sewage Sludge, 1999). Our results are consistent with earlier studies that have enumerated over $5 \log$ CFU E. coli in dewatered MBs from the Guelph wastewater treatment plant that was used in our study (Van Frankenhuyzen et al., 2013), and 4.8 log gene copies g-1 dry solids from dewatered biosolids from a wastewater plant in Minnesota (Burch et al., 2014). The Lystek MB contained no culturable E. coli, but, the ALLBAC marker was detected in both field years (Table 1). Production of Lystek involves a high heat and alkalization using a limestabilization process that aims to kill culturable cells such as $E$. coli (Singh et al., 2006). As expected, in both field seasons, swine manure contained 
the highest number of ALLBAC and culturable $E$. coli $(P=0.02)$, relative to the other MBs (Table 1).

Table 1 - Mean estimate and standard error $(\alpha=0.05)$ of culturable E. coli (CFU $(g)^{-1}$ dry matter) and 16S rRNA Bacteroides spp. markers (copies $(\mathrm{g})^{-1}$ dry matter) contained in soil amendments $(n=10)$ used for the 2011 and 2012 field season.

\begin{tabular}{|c|c|c|c|c|c|}
\hline $\begin{array}{l}\text { Field } \\
\text { season }\end{array}$ & Amendment & $\begin{array}{l}\text { Log E. coli } \\
\text { CFU }(\mathbf{g})^{-1} \\
\text { dry matter }\end{array}$ & $\begin{array}{l}\text { Log } \\
\text { ALLBAC } \\
\text { copies }(g)^{-1} \\
\text { dry matter }\end{array}$ & $\begin{array}{l}\text { Log Hf183 } \\
\text { copies }(g)^{-1} \\
\text { dry matter }\end{array}$ & $\begin{array}{l}\text { Log PIG- } \\
\text { BAC-1 } \\
\text { copies }(\mathrm{g})^{-1} \\
\text { dry matter }\end{array}$ \\
\hline \multirow[t]{5}{*}{2011} & Dewatered & $6.25 \pm 0.04$ & $5.59 \pm 0.24$ & $1.89 \pm 1.17$ & $1.89 \pm 1.6$ \\
\hline & Liquid & $\mathrm{NA}^{a}$ & $7.72 \pm 0.66$ & $2.48 \pm 0.91$ & $5.09 \pm 0.13$ \\
\hline & Lystek & $\mathrm{NC}^{\mathrm{b}}$ & $5.41 \pm 0.21$ & ND & ND \\
\hline & MAP fertilizer & $\mathrm{NC}$ & $\mathrm{ND}^{\mathrm{c}}$ & $\mathrm{ND}$ & ND \\
\hline & Swine manure & $9.15 \pm 0.23$ & $11.6 \pm 0.13$ & ND & $9.57 \pm 0.32$ \\
\hline \multirow[t]{5}{*}{2012} & Dewatered & $7.59 \pm 0.01$ & $6.90 \pm 0.46$ & $4.23 \pm 0.06$ & $4.72 \pm 0.15$ \\
\hline & Liquid & $5.54 \pm 1.50$ & $7.26 \pm 0.09$ & $2.50 \pm 1.1$ & ND \\
\hline & Lystek & $\mathrm{NC}$ & $3.77 \pm 0.16$ & ND & ND \\
\hline & MAP fertilizer & NC & ND & ND & ND \\
\hline & Swine manure & $8.17 \pm 0.02$ & $9.73 \pm 0.14$ & $\mathrm{ND}$ & $7.32 \pm 0.01$ \\
\hline
\end{tabular}

${ }^{a}$ No result available.

${ }^{\mathrm{b}}$ No culturable E. coli growth on differential coliform agar.

' Below quantitative PCR Detection Limit of $10^{1}$.

The human-specific Bacteroides spp. marker ( $\mathrm{Hf} 183)$ was detected in both dewatered and liquid MBs, but not in Lystek or swine manure (Table 1) in both years. Levels were higher than recently reported by Burch et al. (2014) who detected $<18$ gene copies human-specific Bacteroides $\mathrm{g}^{-1} \mathrm{dw}$ ) in dewatered municipal biosolids from wastewater plants in Minnesota that use residual anaerobic digestion for residual solids treatment. The specificity of the HF183 marker primers has been reported as being between 96 and $100 \%$ over a number of geographic locations including Canada, USA, UK, Ireland, Portugal, Belgium, and France; and in a number of metagenomic samples including wastewater, freshwater, marine water, soil and feces (Edge et al., 2010; Gawler et al., 2007; Rogers et al., 2011; Seurinck et al., 2005).

The swine specific Bacteroides spp. marker (PIG-BAC-1) was detected in the highest numbers (9.57 log PIGBAC ( $\mathrm{g})^{-1}$ dry soil in 2011) in swine manure, but was also detected in the liquid MB in 2011, and the dewatered MBs in 2011 and 2012 (Table 1). Lamendella et al. (2009) also found PIG-BAC-1 to cross amplify with human sources as 
well as horse, raccoon, and chicken. The genetic sequences of host-specific Bacteroides spp. can be influenced by particular farming practices, such as the proximity of the host to other animals and diet (Fogarty and Voytek, 2005). The PIGBAC-1 primers were developed using swine-specific Prevotella clades from two small pig farms in Japan (Okabe et al., 2007) and may not be well suited for tracking pigspecific fecal impacts in the geographic region of our study.

\subsection{Detection of E. coli and Bacteroides spp. markers in soil}

Culturable E. coli was detected in lysimeter soils prior to receiving amendment in 2012 (Fig. 1b). Background levels of E. coli detected in 2012 may be due to a pre-tillage event applied prior to amendment application. Tillage can release resident soil bacteria, including E. coli trapped in aggregates (Ishii et al., 2006). In 2011, 2012, soils receiving dewatered or Lystek MBs or swine manure contained higher concentrations of culturable E. coli, compared to the MAP fertilizer control plots which contained none (Fig. 1a and b). This was expected for dewatered and swine manure since these amendments contained the highest concentration of culturable E. coli (Table 1). E. coli was detected in the soil in significant amounts in all treatments for 6 DAA in 2011 or 8 DAA in 2012 (Fig. 1a and b). When culturable E. coli was detected in soil on later dates, it was only found in 1/4 or 2/3 lysimeter replicates in 2011 and 2012, respectively. It appears that the Lystek treatment may have triggered regrowth of $E$. coli in the soil as this microorganism was not detected in the product prior to land application, but was found to increase in soil to concentrations of $6.5 \log$ and $2.3 \log$ CFU (g) $)^{-1}$ dry soil in 2011 and 2012, respectively (Fig. 1a and b). Microbial regrowth in soil has been suggested under nutrient and moisture rich conditions (Dazzo et al., 1973; Samarajeewa et al., 2012).

The ALLBAC marker was detected in soils prior to amendment at $1.5 \log$ ALLBAC $(\mathrm{g})^{-1}$ dry soil in 2011 and over $3.2 \log$ ALLBAC (g)-1 dry soil in 2012 (Fig. 1c and d). In addition, it was detected for 29 or 119 DAA in 2011 and 8 DAA in 2012 (Fig. 1c and d). ALLBAC was detected approximately 5 or 15 times longer in soil than culturable $E$. coli. Our findings would suggest that the ALLBAC marker detects indigenous soil Bacteroides spp. Recent studies have found that Bacteroides-Prevotella are more 
ubiquitous outside the gut than what was once hypothesized (Byappanahalli et al., 2006; van der Wielen and Medema, 2010; Vierheilig et al., 2012; Whitman et al., 2014). The persistence of the ALLBAC marker and it being detected prior to MB or manure application in soil diminishes the utility of this marker to detect recent fecal pollution events.

Human-specific fecal indicators persisted in soil for short periods of time and were not detected prior to amendment. Soils receiving dewatered and liquid MBs contained detectable levels of Hf183 marker up to 6 DAA in 2011, but none were detected in any other treatments or during the entire 2012 field season (Fig. 1e and f). Our results were similar to those reported by Burch et al. (2014) who found that in a soil microcosm study conducted indoors, lacking environmental variables such as water fluctuations and sunlight that are known to affect marker persistence, the human-specific marker was only detected immediately after microcosms were amended with $100 \mathrm{~g} \mathrm{~kg}^{-1}$ of treated Dewatered MBs. The persistence of the host-specific markers found for the current study was also similar to results reported by Piorkowski et al., (2014) who detected the cow-specific Cow-M2 Bacteroides spp. markers for up to 6 DAA in soils receiving liquid dairy manure. The short persistence of these host-specific markers suggests that they are suitable for FST to identify recent or repetitive fecal pollution events. In contrast, PIG-BAC-1 was detected in soil receiving pig manure for up to 29 DAA in 2011 and 8 DAA in 2012 (Fig. 1g and h); however, this marker was also detected for up to 141 DAA in $1 / 4$ lysimeter replicates receiving DW MBs. PIG-BAC- 1 was also detected prior to amendment in 2012 (Fig. 1h) and in MBs (Table 1) suggesting cross-reactivity with nonpig sources, and highlighting the need for appropriate primer design and testing under local conditions. Future research should focus on high-throughput sequencing of the general and host-specific Bacteroides spp. obtained from a wide range of geographically and host diverse fecal samples. This would give us more insight on their genetic diversity, distribution and usefulness in FST.

\subsection{Detection of $E$. coli and Bacteroides spp. markers in soil leachate}

The concentration and total load of ALLBAC markers and culturable E. coli was determined in the leachate over the entire sampling period in the 2011 (data not shown) 
and 2012 (Fig. 2) seasons. We focused on the 2012 field data due to the presence of background levels of E. coli and ALLBAC (Figure S.2) in the leachate resulting from differences in methodology during the 2011 field season. Low levels (0.14 log CFU per $100 \mathrm{~mL}$ ) of $E$. coli were found in leachate from lysimeters receiving the MAP fertilizer control (Fig. 2). This can be attributed to background presence of culturable $E$. coli (Byappanahalli et al., 2006; Vierheilig et al., 2012; Yamahara et al., 2007) or local wildlife, as the GTI property is known to be frequented by raccoons, deer, fox, coyotes, and Canada geese. Though differences in culturable E. coli concentration between dewatered biosolids $(p \leq 0.1)$ were observed over the MAP fertilizer control, there was no difference between treatments in terms of the total loads. The total culturable $E$. coli loads did, however; follow similar trends (Fig. 2) with a 1-2 log-fold difference between MBs and the MAP fertilizer control. E. coli loads in leachate were higher (between 2.5 and $3.7 \log$ CFU $\left(100 \mathrm{~mL}^{-1}\right)$ than Health Canada's ( $\leq 2.3 \log$ E. coli $100 \mathrm{~mL}^{-1}$ ) and EPA's ( $\leq 2.1 \log \mathrm{E}$. coli $100 \mathrm{~mL}^{-1}$ ) recommendations for recreational freshwaters in plots receiving all treatments except the MAP fertilizer control (Health Canada, 2012; USEPA, 2012). 

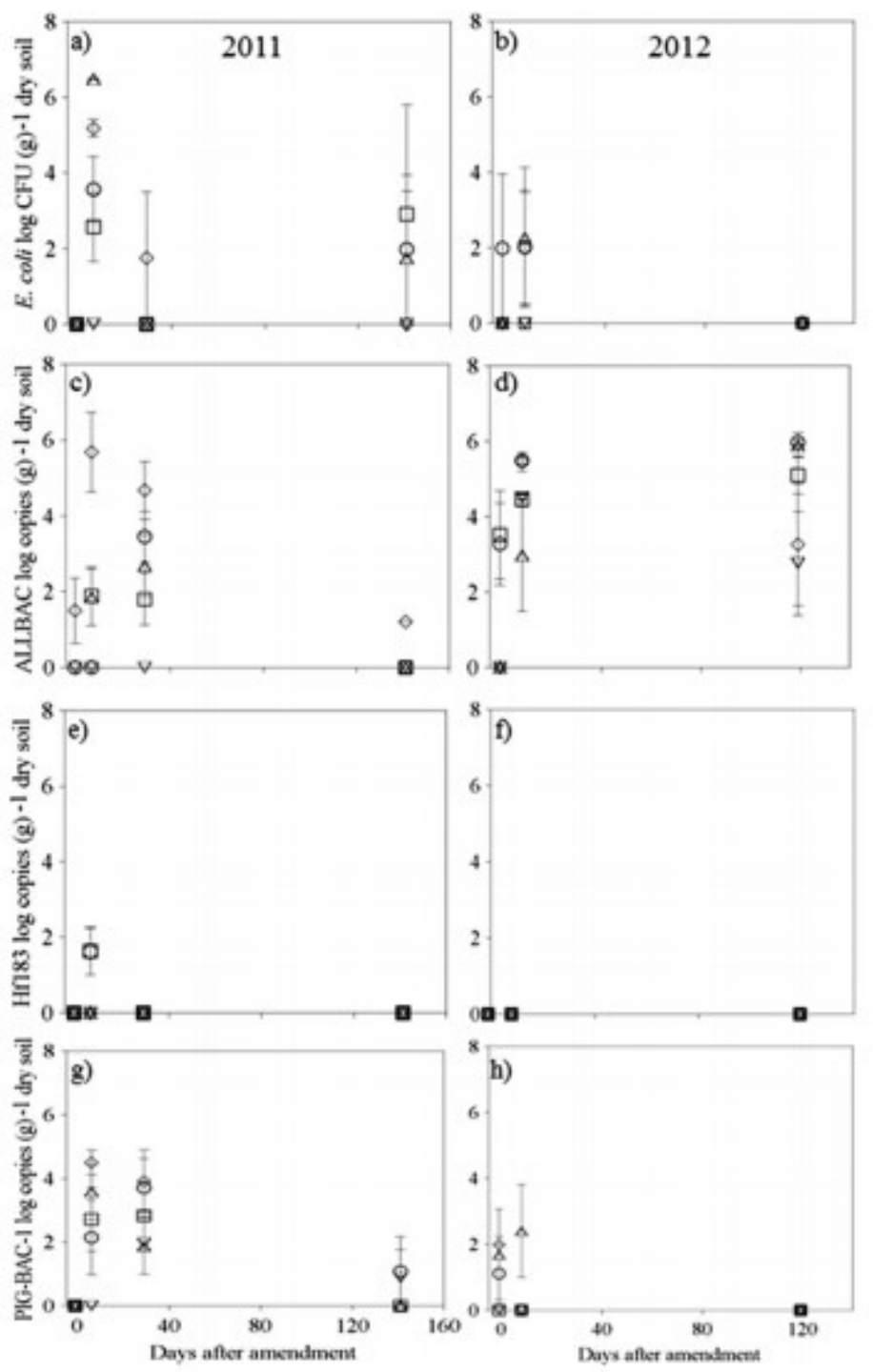

Fig. 1 - Mean concentration of culturable E. coli ( $a$ and b), ALLBAC (c and d), Hf183 (e and f) and PIG-BAC-1 ( $g$ and $h$ ) in soil over the 2011and 2012 field seasons. All mean abundance and enumeration values are represented at $-1,6,29$ and 141- and $-1,9$ and 119 days following amendment application in 2011 and 2012 respectively with dewatered $(\circ)$, liquid $\left({ }^{\circ}\right)$, and Lystek $(\Delta)$ biosolids, MAP fertilizer $(\nabla)(11-52-0)$ and swine manure $(\diamond)$. Error bars represent a calculated standard error of the mean $(\alpha=0.05)$. 

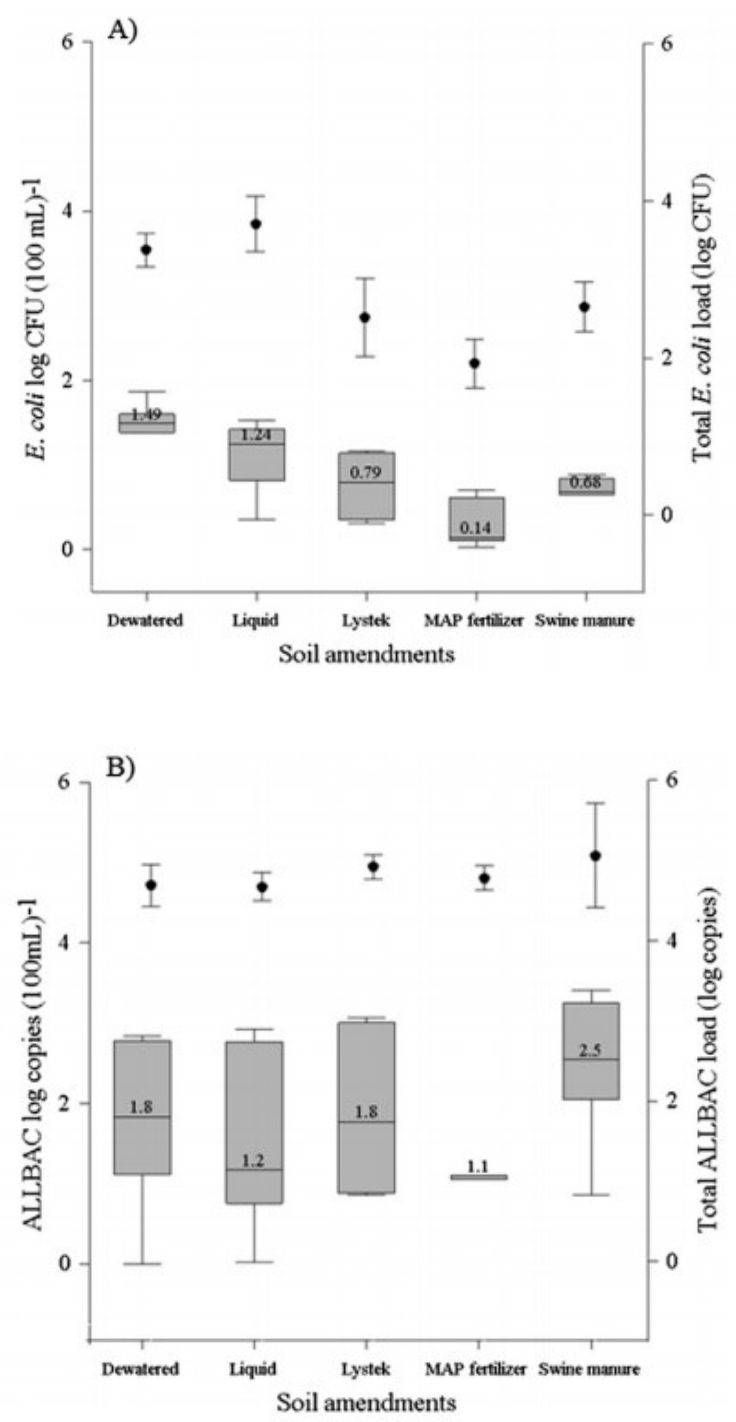

Fig. 2 - Concentrations in leachate (box plot) and total load $(\bullet)$ of culturable E. coli (CFU $100 \mathrm{~mL}^{-1}$ (a) and 16S rRNA genetic marker specific to all Bacteroides-Prevotella (copies $100 \mathrm{~mL})^{-1}$ (b) based on a repeated measures analysis of 7-9 sampling times ( $\mathrm{n}$ = 105) over the 2012 field season field season. Box plots represent the median and quartiles of the pooled data from the entire sampling season. Whiskers represent minimum (lower) and maximum (upper) concentration of fecal indicators. The total fecal indicator load is a summation of the average daily load which is the product of concentration and the total volume contained within each lysimeter at each sampling period. Error bars for total load data represent a calculated standard error of the mean $(\alpha=0.05)$.

ALLBAC was found in leachate samples from lysimeters receiving all amendments over the 2011 and 2012 field seasons, with no significant difference observed between MB amendments or control treatments (Fig. 2). Furthermore, ALLBAC was detected in leachate at a range of about 1-3 log ALLBAC copies $(100 \mathrm{~mL})^{-1}$ prior to amendment in 
2011 and 2012 (Figure S.2). Collectively, this suggests that the presence of the general Bacteroides-Prevotella marker does not necessarily indicate the occurrence of a recent fecal pollution event. As in previous studies, such as Lee et al. (2014), abundance of ALLBAC indicators correlated with $E$. coli $(\mathrm{R}=0.30, \mathrm{P}=0.0075)$; however, only significantly in the 2012 season, and the weak correlation suggests that other factors are driving this relationship.

No Hf183 or PIG-BAC-1 markers were detected in leachate samples. As observed, the relatively short persistence of host specific Bacteroides spp. markers in soil (Fig. 1) suggests their decay in soil would occur prior to their detection in leachate. The lack of Hf183 markers in the leachate samples could also be due to the smaller load applied compared to the mean total load of culturable E. coli and ALLBAC applied (Table 1). Under extreme conditions, such as flooding or intense rainfall that could cause preferential flow, or under conditions of extremely high amendment application rates (McFarland et al., 2012; McMurry et al., 1998; Stoddard et al., 1998), Hf183markers may be detected in leachate. Few studies have quantified human pathogens in biosolids; however, it is understood that they are often present in orders of magnitude lower than fecal indicator bacteria such as E. coli (Guzman et al., 2007; Sidhu and Toze, 2009). Therefore, it is likely that human-specific markers, such Hf183 make a better proxy for human pathogens to test for presence and transport through a soil profile, although differences in size and surface charges between specific human pathogens and Hf183 may affect transport properties (Simoni et al., 1998).

\subsection{Nutrient and metals load in MBs and swine manure}

In this study, Liquid MBs contained twenty times higher concentration of $\mathrm{NO}_{3}-\mathrm{N}$ compared to the other MBs, while the MBs with higher \% total solids, dewatered and Lystek, contained higher $\mathrm{NH}_{4}-\mathrm{N}$ concentrations (Table 2). After anaerobic digestion, soluble anions and cations like nitrate have been found to remain in the liquid portion, while ammonium remains in the solid portion (Lu et al., 2012). Dewatered and Lystek also contained the highest concentrations of total-P (Table 2). In the wastewater treatment process, ferrous chloride is used to precipitate phosphorus. Though this process aids in wastewater treatment, any residuals of this insoluble compound not 
skimmed or filtered can end up in the solid sludge used further for biosolid production; therefore, there is usually a higher presence of phosphorus in biosolids containing higher total solids (Singh et al., 2006). All metals tested (As, Cd, Cr, Co, Cu, Pb, Mo, Ni, $\mathrm{Se}, \mathrm{Zn}$ and $\mathrm{Hg}$ ) were highest in the dewatered and Lystek MBs (Table S.1). Since the MBs were treated anaerobically they can contain EPS-bound pollutants such as heavy metals (Neyens et al., 2004; Singh et al., 2006). Though metal concentration was observed to be different between amendments, all concentrations fell below required limits set forth in 267/03 Ontario Nutrient Management Act and US Protection of the Environment 40 CFR Part 503 (Ontario, 2002; Standards for the Use or Disposal of Sewage Sludge, 1999).

Table 2 - Concentration of nutrients contained in soil amendments during the 2012 field season. Amendments were applied to soil within one day prior after collection.

\begin{tabular}{|c|c|c|c|c|}
\hline Amendment & $\begin{array}{l}\text { TKN mg (kg) })^{-1} \\
\text { dry matter }\end{array}$ & $\begin{array}{l}\mathrm{NO}_{3}-\mathrm{N} \mathrm{mg} \\
(\mathrm{kg})^{-1} \text { dry } \\
\text { matter }\end{array}$ & $\begin{array}{l}\mathrm{NH}_{4}-\mathrm{N} \mathrm{mg} \\
\left(\mathrm{kg}^{\mathrm{l}}\right)^{-1} \text { dry } \\
\text { matter }\end{array}$ & $\begin{array}{l}\text { Total-P mg }(\mathrm{kg})^{-1} \\
\text { dry matter }\end{array}$ \\
\hline Dewatered & $4.43 \times 10^{4}$ & 5.08 & $2.62 \times 10^{3}$ & $2.63 \times 10^{4}$ \\
\hline Liquid & $1.54 \times 10^{5}$ & 215 & $6.06 \times 10^{2}$ & $8.02 \times 10^{3}$ \\
\hline Lystek & $4.39 \times 10^{4}$ & 11.3 & $3.3 \times 10^{3}$ & $2.40 \times 10^{4}$ \\
\hline Swine manure & $6.81 \times 10^{4}$ & 169 & $5.55 \times 10^{2}$ & $2.18 \times 10^{4}$ \\
\hline
\end{tabular}

\subsection{Nutrient and metal persistence in soil and transfer to leachate (2012 season} only)

\subsubsection{Phosphorus}

An increase above background levels of total-P was observed in soils receiving swine manure, Lystek, and liquid 8 DAA (Fig. 3a). For dewatered and MAP, total-P levels remained at or just below background levels, respectively, in the same time period (Fig. 3a). By the end of the field season, 119 DAA, a significant increase in total-P was observed for all treatments with a mean increase between 73 and $338 \mathrm{mg}$ total- $\mathrm{P}(\mathrm{kg})^{-1}$ dry weight soil (Fig. 3a). There was no significant difference between the concentration of total-P in soils receiving $M B$, swine manure or inorganic fertilizer. The total-P transferred to the leachate increased significantly in lysimeters receiving dewatered, liquid and Lystek MBs as well as swine manure, compared to the MAP fertilizer, with over a $100 \mathrm{mg}$ total-P $(\mathrm{L})^{-1}$ increase observed 33 DAA (Fig. 3b). Total-P contained in 
leachate from all plots was higher than the level $\left(200 \mathrm{mg}\right.$ total-P $\left.(L)^{-1}\right)$ for the Canadian trigger range guidelines for every trophic status in freshwater and US EPA guidelines for every ecoregion within the U.S. (Fig. 3b) (CCME, 2004; U.S. EPA, 2000a, 2000b). Preferential flow caused by rainfall plus irrigation as well as the release of microbial-P through drying and wetting periods could be contributing to the high total-P in leachate. Transport of total-P observed in this study could also be due to preferential flow from heavy rainfall and/or irrigation to plots occurring at the beginning of the 2012 sample season (Figure S.2). Regardless of the cause for transport, the increase in total-P in the leachate to concentrations above recommended guidelines could be detrimental to receiving waters in terms of eutrophication (Turner and Haygarth, 2000). These results stress the importance in considering not only the nitrogen content, as is typically done, but the amount of phosphorus in the soils and MBs.

\subsubsection{Nitrate-N and Ammonium-N}

The concentration of $\mathrm{NO}_{3}$ decreased between 1.4 and $5.1 \mathrm{mg} \mathrm{NO}_{3}-\mathrm{N}(\mathrm{kg})^{-1}$ dry weight soil over background levels in soils receiving all amendments with no significant difference in concentrations observed between amendments (Fig. 3c). The decrease in $\mathrm{NO}_{3}-\mathrm{N}$ in soils could be due to plant uptake (Barton et al., 2005) or denitrification (Oertel and Nicklow, 2003); however, the likely cause is transport through leaching (Santibáñez et al., 2007; Soriano-Disla et al., 2011). An increase in the concentration of $\mathrm{NH}_{4}-\mathrm{N}$ was observed 8 DAA with the highest increase in $\mathrm{NH}_{4}-\mathrm{N}$ concentration observed in soils receiving Lystek at $2.9 \mathrm{mg} \mathrm{NH}_{4}-\mathrm{N}(\mathrm{kg})^{-1}$ dry weight soil. Soils receiving the swine manure and MAP fertilizer controls showed the lowest increase at 0.2 and $0.5 \mathrm{mg} \mathrm{NH}_{4}$ $\mathrm{N}(\mathrm{kg})^{-1}$ dry weight soil respectively (Fig. 3e). By the end of the sampling period (119 DAA) the concentration of $\mathrm{NH}_{4}-\mathrm{N}$ in soil decreased back to background levels in all plots (Fig. 3e). The decrease in $\mathrm{NH}_{4}-\mathrm{N}$ could be due to nitrogen assimilation through plant uptake (Barton et al., 2005), volatilization (Van der Weerden and Jarvis, 1997), or nitrification (Paranychianakis et al., 2013).

Leachate obtained from plots receiving dewatered and Lystek MBs contained the highest increase in the concentration of $\mathrm{NO}_{3}-\mathrm{N}$ which was found to be 3 to 8 times (Fig. 3d) the maximum contaminant limit of $10 \mathrm{mg} \mathrm{NO}_{3}-\mathrm{N}(\mathrm{L})^{-1}$ established by the US EPA 
(Wentz et al., 2011) and exceeded long-term guidelines set forth by the CCME for the protection of freshwater aquatic life (CCME, 2007). High $\mathrm{NO}_{3}-\mathrm{N}$ contained in leachate may suggest nitrification of relatively immobile $\mathrm{NH}_{4}-\mathrm{N}$ to mobile $\mathrm{NO}_{3}-\mathrm{N}$ after land application of MBs with high $\mathrm{NH}_{4}-\mathrm{N}$ content (Table 2). Soriano-Disla et al. (2011) reported a positive correlation between $\mathrm{pH}$ and nitrification following application of sewage sludge. Lystek has been shown to have a pH between 8.4 and 9.0 while dewatered biosolids have a pH between 7.2 and 7.6 (City of Guelph, 2012). Nitrification is also likely as the soil becomes warmer and more aerated over the summer-season (Paranychianakis et al., 2013). Column studies by Santibáñez et al. (2007) and Mailapalli (2012) and a field study by Tesfamariam et al. (2009) showed similar increases in leached $\mathrm{NO}_{3}-\mathrm{N}$, exceeding North American recommended levels (CCME, 2007; Wentz et al., 2011) on perennial ryegrass plots following the application of MBs and sewage sludge at lower rates than applied in this study. $\mathrm{NH}_{4}-\mathrm{N}$ concentrations in leachate being fairly steady over the field season following amendment application (Fig. 3f) even with the large load of ammonium applied in treatment (Table 2) is further evidence that a quick conversion to nitrate is occurring.

\subsubsection{Metals}

The concentration of all metals in soils fell within soil quality guidelines set forth by the Canadian Council of Ministers of the Environment (Table S.2), and no metals were detectable in leachate, suggesting no immediate environmental risk in terms of metal loads in soils following MBs application. 


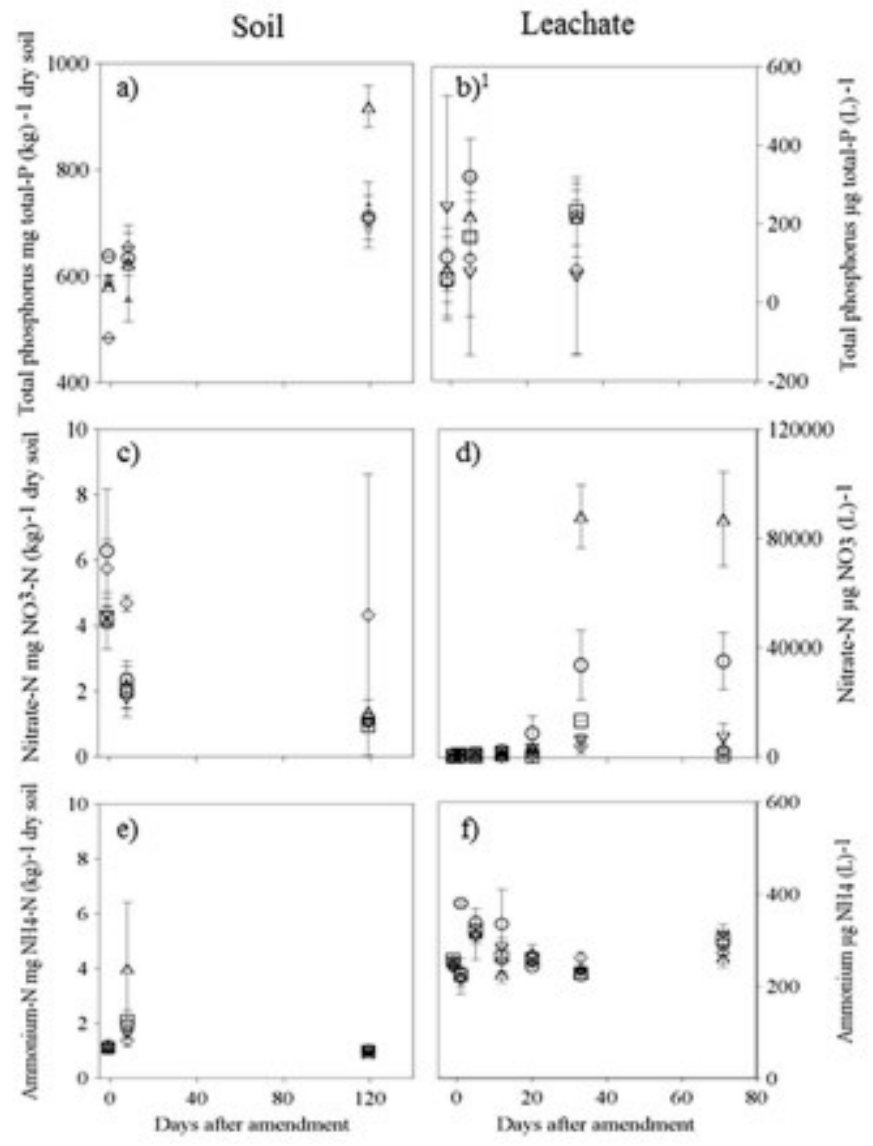

${ }^{1}$ Total-P $(\mathrm{Pt})$ was measured prior to application as well as 5 and 33 days following amendment for leachate result

Fig. 3 e Mean concentration total-P (a and b), $\mathrm{NO}_{3}-\mathrm{N}$ (c and d) and $\mathrm{NH}_{4}-\mathrm{N}$ (e and f) in soil and leachate during the 2012 field season. All mean abundance and enumeration values are represented for soil at $-1,8$ and 119 and for leachate at $-1,1,5,12,20,33$, and 71 days following amendment with dewatered $(0)$, liquid ( ${ }^{\circ}$, and Lystek $(\Delta)$ biosolids, MAP fertilizer $(\nabla)(11-52-0)$ and swine manure $(\diamond)$. Error bars represent a calculated standard error of the mean $(\alpha=0.05)$.

\section{Conclusions}

- Land application of both CP1/Class A and CP2/Class B MBs can lead to drainage and surface water contamination based on an increased concentration of fecal indicators, $\mathrm{NO}_{3}-\mathrm{N}$ and total-P found in leachate samples.

- The human-specific Bacteroides spp. marker, Hf183 was identified in MBs at low levels, showed no cross reactivity, and had low persistence in the environment making it useful during recent pollution events and following surface runoff. 
- The land application of CP1/Class A Lystek biosolids caused the highest impact on soil and leachate samples due to a high transfer of nutrients while samples amended with CP2 dewatered biosolids contained the highest transfer of culturable E. coli, and the Hf183 and PIG-BAC-1 markers.

- Metals accumulation and transfer through soil and surface water leachate were negligible or non-existent following land application of MBs and were therefore not considered a risk to ground- or surface waters in this study.

\section{Acknowledgements}

This study was funded by the Ontario Ministry of Agriculture Food, and Rural Affairs and C.M. was funded by a Natural Sciences and Engineering Research Council of Canada postgraduate scholarship. We would like to thank employees at the Guelph Turfgrass Institute as well as Michael Allan Merchant for all their help with experimental set-up.

\section{Appendix A. Supplementary data}

Supplementary data related to this article can be found at 10.016/j.watres.2014.12.004

\section{References}

Bae, S., Wuertz, S., 2009. Rapid decay of host-specific fecal Bacteroidales cells in seawater as measured by quantitative PCR with propidium monoazide. Water Res. 43, 4850-4859. http://dx.doi.org/10.1016/j.watres.2009.06.053.

Barton, L., Schipper, L.A., Barkle, G.F., McLeod, M., Speir, T.W., Taylor, M.D., McGill, A.C., van Schaik, A.P., Fitzgerald, N.B., Pandey, S.P., 2005. Land application of domestic effluent onto four soil types: plant uptake and nutrient leaching. J. Environ. Qual. 34, 635-643.

Bernhard, A.E., Field, K.G., 2000. A PCR assay to discriminate human and ruminant feces on the basis of host differences in bacteroides-prevotella genes encoding 16S rRNA. Appl. Environ. Microbiol. 66, 4571. http://dx.doi.org/10.1128/ AEM.66.10.4571-4574.2000.Updated.

Bibby, K., Viau, E., Peccia, J., 2010. Pyrosequencing of the 16S rRNA gene to reveal bacterial pathogen diversity in biosolids. Water Res. 44, 4252-4260. http://dx.doi.org/10.1016/ j.watres.2010.05.039.

Burch, T.R., Sadowsky, M.J., LaPara, T.M., 2014. Fate of antibiotic resistance genes and class 1 integrons in soil microcosms following the application of treated 
residual municipal wastewater solids. Environ. Sci. Technol. 48, 5620-5627. http://dx.doi.org/10.1021/es501098g.

Byappanahalli, M.N., Whitman, R.L., Shively, D.A., Sadowsky, M.J., Ishii, S., 2006. Population structure, persistence, and seasonality of autochthonous Escherichia coli in temperate, coastal forest soil from a Great Lakes watershed. Environ. Microbiol. 8, 504-513. http://dx.doi.org/10.1111/ j.1462-2920.2005.00916.x.

Canadian Council of Ministers of the Environment, 2004. Canadian Water Quality Guidelines for the Protection of Aquatic Life - Phosphorus: Canadian Guidance Framework for the Management of Freshwater Systems.

Canadian Council of Ministers of the Environment, 2007. Canadian Water Quality Guidelines for the Protection of Aquatic Life - Nitrate lon.

Canadian Council of Ministers of the Environment, 2010. A Review of the Current Canadian Legislative Framework for Wastewater Biosolids. City of Guelph, p. 2012 (Wastewater Annual Report).

Dazzo, F.B., Smith, P., Hubbel, D., 1973. The influence of manure slurry irrigation on the survival of fecal organisms in Scranton fine sand. J. Environ. Qual. 2, 470473.

Edge, T.A., Hill, S., Seto, P., Marsalek, J., 2010. Library-dependent and libraryindependent microbial source tracking to identify spatial variation in faecal contamination sources along a Lake Ontario beach (Ontario, Canada). Water Sci. Technol. 62, 719-727. http://dx.doi.org/10.2166/wst.2010.335.

Fogarty, L.R., Voytek, M.A., 2005. Comparison of bacteroidesprevotella 16S rRNA genetic markers for fecal samples from different animal species. Appl. Environ. Microbiol. 71, 5999-6007. http://dx.doi.org/10.1128/AEM.71.10.5999.

Gawler, A.H., Beecher, J.E., Brandão, J., Carroll, N.M., Falcão, L., Gourmelon, M., Masterson, B., Nunes, B., Porter, J., Rince, A., Rodrigues, R., Thorp, M., Walters, J.M., Meijer, W.G., 2007. Validation of host-specific Bacteroidales $16 \mathrm{~S}$ rRNA genes as markers to determine the origin of faecal pollution in Atlantic Rim countries of the European Union. Water Res. 41, 3780-3784. http://dx.doi.org/10.1016/..watres.2007.01.028.

Guzmán, C., Jofre, J., Montemayor, M., Lucena, F., 2007. Occurrence and levels of indicators and selected pathogens in different sludges and biosolids. J. Appl. Microbiol. 103, 2420-2429. http://dx.doi.org/10.1111/j.1365-2672.2007.03487.x.

Health Canada, 2012. Guidelines for Canadian Recreational Water Quality, third ed. Ottawa, ON.

Ishii, S., Ksoll, W.B., Hicks, R.E., Sadowsky, M.J., 2006. Presence and growth of naturalized Escherichia coli in temperate soils from Lake Superior Watersheds. Appl. Environ. Microbiol. 72, 612-621. http://dx.doi.org/10.1128/AEM.72.1.612. 
Jamieson, R.C., Gordon, R.J., Sharples, K.E., Stratton, G.W., Madani, A., 2002. Movement and persistence of fecal bacteria in agricultural soils and subsurface drainage water: a review. Can. Biosyst. Eng. 44, 1-9.

Lamendella, R., Santo Domingo, J.W., Yannarell, A.C., Ghosh, S., Di Giovanni, G., Mackie, R.I., Oerther, D.B., 2009. Evaluation of swine-specific PCR assays used for fecal source tracking and analysis of molecular diversity of swine-specific "bacteroidales" populations. Appl. Environ. Microbiol. 75, 5787-5796. http://dx.doi.org/10.1128/AEM.00448-09.

Lu, Q., He, Z.L., Stoffella, P.J., 2012. Land application of biosolids in the USA: a review. Appl. Environ. Soil Sci. 2012, 1-11. http:// dx.doi.org/10.1155/2012/201462.

Mailapalli, D.R., 2012. Nitrogen leaching from saybrook soil amended with biosolid and polyacrylamide. J. Water Resour. Prot. 04, 968-979. http://dx.doi.org/10.4236/jwarp.2012.411112.

Maynard, D.G., Karla, Y.P., Crumbaugh, J.A., 2008. Nitrate and exchangeable ammonium nitrogen. In: Carter, M.R., Gregorich, E.G. (Eds.), Soil Sampling and Methods of Analysis. CRC Press, Boca Raton, FL, pp. 71-80.

McFarland, M.J., Kumarsamy, K., Brobst, R.B., Hais, A., Schmitz, M.D., 2012. Groundwater quality protection at biosolids land application sites. Water Res. 46, 5963-5969. http://dx.doi.org/10.1016/j.watres.2012.08.009.

McMurry, S.W., Coyne, M.S., Perfect, E., 1998. Fecal coliform transport through intact soil blocks amended with poultry manure. J. Environ. Qual. 27, 86-92.

Mieszkin, S., Furet, J.-P., Corthier, G., Gourmelon, M., 2009. Estimation of pig fecal contamination in a river catchment by real-time PCR using two pig-specific Bacteroidales 16S rRNA genetic markers. Appl. Environ. Microbiol. 75, 30453054. http://dx.doi.org/10.1128/AEM.02343-08.

MOE, 1997. The Determination of Mercury in Soils, Sediments and Vegetation by Cold Vapour AAS (CV-AAS). HGSSV-E3059.

MOE, 1999. The Determination of Arsenic, Seleneium and Antimony in Vegetation, Compost, Soil and Sediments by Hydride-flameless Atomic Adsorption Spectrophotometry (HYD-FAAS). HYDPSSV-E3245.

MOE, 2002. The Determination of Trace Metals in Soil, Compost, Liquid Effluent and TCLP Leachate by the Spectro Inductively Coupled Plasma-optical Emission Spectrometer (ICP-OES). HMPNSOIL-E3073.

Neyens, E., Baeyens, J., Dewil, R., De heyder, B., 2004. Advanced sludge treatment affects extracellular polymeric substances to improve activated sludge dewatering. J. Hazard. Mater. 106, 83-92. http://dx.doi.org/10.1016/j.jhazmat.2003.11.014.

Oertel, A.O., Nicklow, J.W., 2003. Evaluation of ground water denitrification at a biosolids disposal site. Environ. Monit. Assess. 87, 1-31. 
Okabe, S., Okayama, N., Savichtcheva, O., Ito, T., 2007. Quantification of host-specific Bacteroides-Prevotella 16S rRNA genetic markers for assessment of fecal pollution in freshwater. Appl. Microbiol. Biotechnol. 74, 890-901. http:// dx.doi.org/10.1007/s00253-006-0714-x.

OMAFRA, 2009. Turfgrass Management Recommendations. Ottawa, ON.

Ontario, 2002. Nutrient Management Act O. 267/03. Queens Printer, Ottawa.

Paranychianakis, N.V., Tsiknia, M., Giannakis, G., Nikolaidis, N.P., Kalogerakis, N., 2013. Nitrogen cycling and relationships between ammonia oxidizers and denitrifiers in a clay-loam soil. Appl. Microbiol. Biotechnol. 97, 5507-5515. http:// dx.doi.org/10.1007/s00253-013-4765-5.

Piorkowski, G.S., Bezanson, G.S., James, R.C., Truelstrup Hansen, L., Yost, C.K., 2014. Effect of Hillslope position and manure application rages on the persistence of fecal source tracking indicators in an agricultural soil. J. Environ. Qual. 43, 450-458. http://dx.doi.org/10.2134/jeq2013.07.0274.

Reid, K., 1998. Soil Fertility Handbook, 1998th ed. Ontario Ministry of Agriculture, Food and Rural Affairs. Queen's Printer for Ontario, Toronto, Canada.

Rogers, S.W., Donnelly, M., Peed, L., Kelty, C.A., Mondal, S., Zhong, Z., Shanks, O.C., 2011. Decay of bacterial pathogens, fecal indicators, and real-time quantitative PCR genetic markers in manure-amended soils. Appl. Environ. Microbiol. 77, 4839-4848. http://dx.doi.org/10.1128/AEM.02427-10.

Roy, J.W., Hall, J.C., Parkin, G.W., Wagner-Riddle, C., Clegg, B.S., 2001. Seasonal leaching and biodegradation of dicamba in turfgrass. J. Environ. Qual. 30, 13601370.

Samarajeewa, A.D., Glasauer, S.M., Lauzon, J.D., Halloran, I.P.O., Parkin, G.W., Dunfield, K.E., 2012. Bacterial contamination of tile drainage water and shallow groundwater under different application methods of liquid swine manure. Can. J. Microbiol. 677, 668-677. http://dx.doi.org/10.1139/W2012-038.

Santibáñez, C., Ginocchio, R., Teresa Varnero, M., 2007. Evaluation of nitrate leaching from mine tailings amended with biosolids under Mediterranean type climate conditions. Soil Biol. Biochem. 39, 1333-1340. http://dx.doi.org/10.1016/ j.soilbio.2006.12.009.

Searle, P.L., 1984. The Berthelot or indophenol reaction and its use in the analytical chemistry of nitrogen: a review. Analyst 109, 549-568.

Seurinck, S., Defoirdt, T., Verstraete, W., Siciliano, S.D., 2005. Detection and quantification of the human-specific HF183 Bacteroides 16S rRNA genetic marker with real-time PCR for assessment of human faecal pollution in freshwater. Environ. Microbiol. 7, 249-259. http://dx.doi.org/10.1111/j.14622920.2004.00702.x.

Shanks, O.C., Atikovic, E., Blackwood, A.D., Lu, J., Noble, R.T., Domingo, J.S., Seifring, S., Sivaganesan, M., Haugland, R.A., 2008. Quantitative PCR for 
detection and enumeration of genetic markers of bovine fecal pollution. Appl. Environ. Microbiol. 74, 745-752. http://dx.doi.org/10.1128/AEM.01843- 07.

Sidhu, J.P.S., Toze, S.G., 2009. Human pathogens and their indicators in biosolids: a literature review. Environ. Int. 35, 187-201. http://dx.doi.org/10.1016/j.envint.2008.07.006.

Simoni, S.F., Harms, H., Bosma, T.N.P., Zehnder, A.J.B., 1998. Population heterogeneity affects transport of bacteria through sand columns at low flow rates. Environ. Sci. Technol. 32, 2100-2105.

Singh, A., Mosher, F., Lugowski, A., Ward, O., 2006. An advanced treatment process and potential beneficial applications of the processed biosolids. In: 79th Annual Water Environment Federation Technical Exhibition and Conference, pp. 68866901.

Soriano-Disla, J.M., Gómez, I., Navarro-Pedreño, J., 2011. The influence of soil properties on the water pollution (Nitrate, phosphate and COD) following a single application of sewage sludge to 70 contrasting agricultural soils. Water, Air, \& Soil Pollut. 223, 1783-1790. http://dx.doi.org/10.1007/s11270-011- 0983-6.

Standards for the Use or Disposal of Sewage Sludge, 1999. 40 C.F.R. 503.

Stoddard, C.S., Coyne, M.S., Grove, J.H., 1998. Fecal bacteria survival and infiltration through a shallow agricultural soil: timing and tillage effects. J. Environ. Qual. 27, 1516-1523.

Tambalo, D.D., Fremaux, B., Boa, T., Yost, C.K., 2012. Persistence of host-associated Bacteroidales gene markers and their quantitative detection in an urban and agricultural mixed prairie watershed. Water Res. 46, 2891-2904. http://dx.doi.org/ 10.1016/j.watres.2012.02.048.

Technicon Intrument Corporation, 1971. Nitrate p Nitrite in Water. Industrial Method No. 32-69W. Tarrytown, NY.

Tesfamariam, E.H., Annandale, J.G., Steyn, J.M., Stirzaker, R.J., 2009. Exporting large volumes of municipal sewage sludge through turfgrass sod production. J. Environ. Qual. 38, 1320-1328. http://dx.doi.org/10.2134/jeq2008.0397.

Turner, B.L., Haygarth, P.M., 2000. Phosphorus Forms and Concentrations in Leachate under Four Grassland Soil Types. Soil Sci. Soc. Am. J. 64, 1090-1099. http://dx.doi.org/10.2136/ sssaj2000.6431090x.

USEPA, 1983. Methods for Chemical Analysis of Water and Wastes. EPA $600 / 4 \mathrm{e} 79 / 020$.

USEPA, 1993. Methods for the Determination of Inorganic Substances in Environmental Samples. EPA600/R-93/100.

USEPA, 2000a. Nutrient Criteria Technical Guidance Manual: Lakes and Reservoirs. Washington, DC. EPA-822-B00-001. 
USEPA, 2000b. Nutrient Criteria Technical Guidance Manual: Rivers and Streams. Washington, DC. EPA-822-B00-002.

USEPA, 2007. Microwave Assisted Acid Digestion of Sediments, Sludges, Soils, and Oils.

USEPA, 2012. Recreational Water Quality Criteria.

Van der Weerden, T.J., Jarvis, S.C., 1997. Ammonia emission factors for $\mathrm{N}$ fertilizers applied to two contrasting grassland soils. Environ. Pollut. 95, 205-211.

Van der Wielen, P.W.J.J., Medema, G., 2010. Unsuitability of quantitative Bacteroidales $16 S$ rRNA gene assays for discerning fecal contamination of drinking water. Appl. Environ. Microbiol. 76, 4876-4881. http://dx.doi.org/10.1128/ AEM.0309009.

Van Frankenhuyzen, J.K., Trevors, J.T., Flemming, C.A., Lee, H., Habash, M.B., 2013. Optimization, validation, and application of a real-time PCR protocol for quantification of viable bacterial cells in municipal sewage sludge and biosolids using reporter genes and Escherichia coli. J. Ind. Microbiol. Biotechnol. 40, 12511261. http://dx.doi.org/10.1007/s10295- 013-1319-x.

Viau, E., Peccia, J., 2009. Survey of wastewater indicators and human pathogen genomes in biosolids produced by class a and class B stabilization treatments. Appl. Environ. Microbiol. 75, 164-174. http://dx.doi.org/10.1128/AEM.01331-08.

Vierheilig, J., Farnleitner, A.H., Kollanur, D., Blöschl, G., Reischer, G.H., 2012. High abundance of genetic Bacteroidetes markers for total fecal pollution in pristine alpine soils suggests lack in specificity for feces. J. Microbiol. methods $88,433-$ 435. http://dx.doi.org/10.1016/j.mimet.2012.01.009

Wentz, D.A., Richards, K.D., Martin, J.D., Waite, I.R., 2011. Nutrients from Atmospheric and Urban Sources, Fertilization, and Livestock Wastes Can Contribute to Excessive Algal Growth in Streams.

Whitman, R.L., Byappanahalli, M.N., Spolijaric, A.M., PrzybylaKelly, K., Shively, D.A., Nevers, M.B., 2014. Evidence for freeliving Bacteroides in Cladophora along the shores of the Great Lakes. Aquat. Microb. Ecol. 72, 117-126. http://dx.doi.org/ 10.3354/ame01688.

Yamahara, K.M., Layton, B.A., Santoro, A.E., Boehm, A.B., 2007. Beach sands along the California coast are diffuse sources of fecal bacteria to coastal waters.

Environ. Sci. Technol. 41, 4515-4521. 